\title{
Peranan Peserta KKN Tematik Dalam Meningkatkan Kepatuhan Penggunaan Masker Pada Masa Pendemik Covid-19 di Kota Kendari
}

\author{
Adryan Fristiohady*1, La Ode Muhammad Fitrawan'1, Ruslin1, La Aba², Al Indra Jaya Tamsa1, \\ Amelia1, Anugrahwati Marsuki Putri', Fenny Risky Febriani Azmas, Nabila Tasya Azza \\ Hermansyah ${ }^{1}$ \\ 1,2,3,5,6,7,8,9Fakultas Farmasi, Universitas Halu Oleo Kendari \\ ${ }^{4}$ Lembaga Penelitian dan Pengabdian Masyarakat, Universitas Halu Oleo Kendari \\ *e-mail: adryanfristiohady@uho.ac.id ${ }^{1}$
}

\begin{abstract}
The use of this mask has an important role in anticipating Covid-19 virus. If the community has knowledge about the use of masks, the community will also be obedient in the use of masks. Compliance is to describe the positive behavior of the people shown by using. Through this Thematic Community Service Program, the community can know the benefits of using masks in preventing Covid-19. the method used in the integrated community service activities of Thematic KKN is the method of socialization, the method for the environment of student residence, the method of media networking and reporting methods. Thematic KKN takes place in the city of Kendari, Sulawesi Tenggara.
\end{abstract}

Keywords: Covid-19, masks, Thematic Community Service

\begin{abstract}
Abstrak
Penggunaan masker ini memiliki peranan yang penting dalam mengantisipasi terjadinya virus Covid19. Jika masyarakat memiliki pengetahuan tentang penggunaan masker, maka masyarakat juga akan patuh dalam penggunaan masker tersebut. Kepatuhan ini untuk menggambarkan perilaku positif masyarakat yang diperlihatkan dengan menggunakan. Melalui kegiatan KKN Tematik ini dilakukan agar masyarakat dapat mengetahui manfaat penggunaan masker dalam pencegahan Covid-19. metode yang digunakan pada kegiatan pengabdian masyarakat terintegrasi KKN Tematik ini ialah metode sosialisasi, metode untuk dilingkungan tempat tinggal mahasiswa, metode jejaring media dan metode pelaporan.KKN Tematik berlokasi di kota Kendari, Sulawesi Tenggara
\end{abstract}

Kata kunci: Covid-19, masker, KKN Tematik

\section{PENDAHULUAN}

Awal tahun 2020, dunia di gemparkan dengan adanya virus jenis baru yang bernama coronavirus (SARS-CoV 2) atau bisa juga disebut coronavirus disease 2019 (Covid-19). Virus ini telah diketahui berasal dari daerah Wuhan, Tiongkok dan ditemukan pada akhir bulan desember 2019. Sampai saat ini dipastikan sudah terdapat 65 negara yang terjangkit oleh virus ini. Epedemiologi Covid-19 di Wuhan menunjukan bahwa 66\% pasien yang terpapar virus ini berkaitan dengan pasar seafood atau live market yang berada di Wuhan, Tiongkok (Yuliana, 2020).

Coronavirus adalah sekumpulan virus dari subfamily orthocrona virinae dalam keluarga coronaviridae dan ordo nidovirales. Kelompok virus ini yang dapat menyebabkan penyakit pada burung dan mamalia, termaksud manusia. Pada manusia coronavirus menyebabkan infeksi saluran pernapasan yang umumnya ringan, seperti pilek, meskipun beberapa bentuk penyakit seperti: SARS, MERS, dan COVID-19. Dalam kondisi saat ini, virus corona bukanlah suatu wadah yang bisa diabaikan begitu saja. Jika dilihat dari gejalanya, orang awam akan mengira hanya sebatas influenza biasa, tetapi bagi analisis kedokteran virus ini cukup berbahaya dan mematikan (Yunus dan Annissa, 2020).

Penyebaran virus Covid-19 terjadi sangat cepat, bukan hanya di Indonesia tetapi juga di seluruh dunia. Penyebaran ini melalui kontak fisik langsung dengan cara bersentuhan, virus Covid-19 dapat bertahan hidup hingga 3 hari dengan menempel pada permukaan benda. Oleh karena itu, kita harus rajin cuci tangan karena tangan merupakan anggota tubuh yang paling 
banyak melakukan aktivitas dan melakukan interaksi dengan orang lain atau benda yang ada disekitar. Ketika berada diluar rumah kita harus selalu menggunakan masker dan menghindari kerumunan orang banyak untuk mencegah penyebaran virus Covid-19 (Zendrato, 2020).

Berdasarkan data dari media center percepatan Covid-19 di Kota Kendari pada tanggal 13 Juli 2020, juru bicara dr. Algazali Amirulah mengatakan bahwa terjadi penambahan pemantauan untuk OTG (Orang Tanpa Gejala) sebanyak 6 orang dari kecamatan Poasia, Kelurahan Wundungbatu karena riwayat kontak erat dengan pasien positif sebelumnya atau keluarga dekat sehingga akumulasi jumlah OTG sebanyak 684 orang, dimana setelah pemantauan sebanyak 415 orang dan dalam proses pemantauan sebanyak 269 orang. Untuk PDP (Pasien Dalam Pengawasan) sebanyak 68 orang, dimana setelah pemantauan 66 orang dan dalam proses perawatan 2 orang. Untuk positif sebanyak 103 orang, pasien yang dinyatakan sembuh sebanyak 74 orang, pasien dalam proses perawatan sebanyak 25 orang dan dinyatakan meninggal 4 orang. Oleh karena itu, mari kita sama-sama meningkatkan kewaspadaan dan kepeduliaan, jangan tertular dan jangan menulari. Ingat untuk tetap menggunakan masker ketika di luar ruangan atau ketika beraktivitas dengan orang lain dan selalu mengikuti himbauan pemerintah.

Peraturan dalam penggunaan masker dan himbauan untuk mencuci tangan masih sangat ada yang mengabaikan untuk mengikuti peraturan tersebut. Hal ini dikarenakan juga kurangnya pengetahuan yang dimiliki masyarakat dan langkahnya masker dikalangan masyarakat. Oleh sebab itu, perlu adanya ketersediaan fasilitas cuci tangan di rumah maupun di tempat umum serta pengunaan masker yang baik dan benar di tempat umum. Jika tidak ada hal penting, masyarakat di himbau untuk tetap melakukan aktivitas atau tinggal di rumah, beribadah dari rumah dan menghindari aktivitas massal (Natalia dkk., 2020).

Pandemi virus Covid-19 ini merupakan masalah yang sangat serius karena telah banyak menimbulkan korban jiwa. Selain itu, virus Covid-19 ini dapat menyebar dengan cepat melalui manusia ataupun benda yang menjadi perantara. Penggunaan masker ketika keluar rumah merupakan salah satu upaya untuk meminimalisirkan penuluran virus Covid-19. Seiring waktu dengan adanya virus Covid-19 ini, menjadikan masker langkah dan harga yang sangat melambung tinggi dipasaran terutama masker medis. Kelangkaan masker tersebut membuat pemerintah membatasi penggunaan masker medis hanya untuk tenaga kesehatan saja, maka dengan begitu adanya hal tersebut di dapatkan alternatif untuk penggunaan masker bagi masyarakat umum agar dapat digunakan sehari-hari yaitu dengan menggunakan masker kain (Armiani dkk., 2020).

Pengetahuan tentang cara menghindari penyakit sangat di butuhkan saat ini, terutama dalam menghadapi virus Covid-19. Salah satu pengetahuan yang dibutuhkan untuk pencegahan virus Covid-19 ialah dengan penggunaan masker. Penggunaan masker ini memiliki peranan yang penting dalam mengantisipasi terjadinya virus Covid-19. Jika masyarakat memiliki pengetahuan tentang penggunaan masker, maka masyarakat juga akan patuh dalam penggunaan masker tersebut. Kepatuhan ini untuk menggambarkan perilaku positif masyarakat yang diperlihatkan dengan menggunakan masker (Sari dkk., 2020).

Cara yang dilakukan dalam pertahanan utama diri sekaligus dalam mencegah penularan Covid-19 ialah dengan tinggal dirumah, rajin mencuci tangan, menjaga kebersihan, menggunakan alat pelindung diri (APD), jika keluar rumah harus menjaga jarak minimal 1-2 meter dan menggunakan masker. Masker yang digunakan harus bisa tahan terhadap debu serta udara yang terkontaminasi seperti polutan, menggunakan masker yang bisa melindungi dari partikel virus atau bakteri sehingga tidak masuk ke dalam sistem pernapasan. Sebelum adanya virus Covid-19 WHO merekomendasikan penggunaan masker hanya untuk masyarakat yang sakit, tetapi semenjak adanya virus Covid-19 ini dan penyebarannya semakin cepat anjuran tersebut pun di ubah. Masker yang bisa digunakan untuk masyarakat yang tidak sakit ialah masker kain. Masker kain merupakan masker yang berbentuk seperti masker medis namun masker kain ini menggunakan bahan dasar kain yang lebih tebal dan bisa di gunakan berulang kali tetapi dengan syarat harus di cuci bersih. Masker kain juga bisa memilki banyak warna dan variasi yang bisa terbuat dari kain biasa, katun ataupun kaos (Dewi dan Sri, 2020). 
Berdasarkan hal tersebut diatas maka akan dilakukan kegiatan KKN Tematik mengenai penguatan peran warga masyarakat dalam mitigasi dan adaptasi menghadapi wabah Covid-19 di Kota Kendari untuk mencapai tujuan dalam penguatan peran warga masyarakat dalam menghadapi Wabah Covid-19 maka dilakukan gerakan menggunakan masker (GEMAS) yang merupakan sebuat gerakan yang bertujuan untuk memberitahukan kepada masyarakat Kota Kendari bagaimana pentingnya penggunaan masker dan bagaimana cara menggunakan masker yang baik dan benar dalam pencegahan wabah Covid-19.

\section{METODE}

Melalui kegiatan KKN Tematik ini dilakukan agar masyarakat kecamtan poasia, kecamatan kambu, kecamatan kendari barat, kec. Wua-wua, Kec. Puuwatu, dan Kec. Kendari dapat mengetahui Manfaat penggunaan masker dalam pencegahan Covid-19 serta mengetahui cara pembuatan masker dan mengelola masker tersebut dengan menggunakan Gerakan GEMAS (Gerakan Menggunakan Masker) tetapi tetap dalam social distancing dan physical distancing.

Metode dari kegiatan ini adalah sebagai berikut:

1. Mensosialisasikan kepada masyarakat mengenai materi gerakan menggunakan masker (GEMAS) yang sudah di persiapkan dengan metode online melalui whatsapp.

2. Mensosialisasikan dan mempraktikan cara kepada masyarakat mengenai materi gerakan menggunakan masker (GEMAS) yang telah dipersiapkan dengan metode offline.

3. Membagikan souvenir berupa masker dan handsanitizer kepada masyarakat yang telah dilakukan sosialisasi baik secara online dan offline.

Tujuan dari kegiatan ini adalah sebagai berikut:

1. Masyarakat dapat memahami mengenai manfaat penggunaan masker untuk mencegah penyebaran Covid-19 sehingga dapat meningkatnya kepatuhan masyarakat dalam penggunaan masker untuk mencegah penularan Covid-19.

2. Masyarakat mampu membedakan jenis-jenis masker medis dan non-medis.

3. Masyarakat dapat menerapkan hal-hal yang disosialisasikan seperti menggunakan masker dengan cara yang baik dan membuang masker dengan cara yg baik.

\section{HASIL DAN PEMBAHASAN}

Pengabdian kepada masyarakat adalah usaha untuk menyebarluaskan ilmu pengetahuan, teknologi, dan seni kepada masyarakat. Kegiatan tersebut harus mampu memberikan suatu nilai tambah bagi masyarakat, baik dalam kegiatan ekonomi, kebijakan, dan perubahan perilaku (sosial). Uraikan bahwa kegiatan pengabdian telah mampu memberi perubahan bagi individu/masyarakat maupun institusi baik jangka pendek maupun jangka panjang. Kegiatan KKN tematik dilaksanakan bertujuan untuk memberikan pemahaman kepada masyarakat mengenai manfaat penggunaan masker untuk mencegah penyebaran COVID-19.

Meningkatnya angka positif COVID-19 di Indonesia kian melesat dan menjadikan COVID19 ditetapkan sebagai pandemi dunia. Jumlah kasus COVID-19 yang ada di Provinsi Sulawesi Tenggara adalah 521 kasus. Jumlah pasien positif COVID-19 yang ada di Kota Kendari adalah 104 pasien. GEMAS merupakan singkatan dari Gerakan Menggunakan Masker. Menggunakan masker merupakan salah satu langkah menurunkan angka pertambahan positif COVID-19 di Indonesia, khususnya di Kota Kendari. Hal ini Sesuai dengan Anjuran WHO dan pemerintah bahwa dengan menggunakkan masker dapat mengurangi penyebaran COVID-19.

Kegiatan KKN tematik diawali dengan kegiatan pembekalan via daring menggunakan aplikasi zoom. Materi pembekaln KKN Tematik diberikan oleh bapak Dr.rer.nat. Apt. Adryan Fristiohady, S.Farm., M.Sc.dan bapak Apt. La Ode Muhammad Fitrawan, S.Farm., M.Sc. selaku dosen pembimbing lapangan. Kegiatan pembekalan juga diikutkan sekaligus dengan pelepasan 
anggota KKN tematik oleh bapak Dr. Ruslin, M.Si. selaku dekan fakultas farmasi UHO. Kegiatan ini diikuti oleh sebanyak 24 orang mahasiswa KKN Tematik.

Kemudian kegiatan dilanjutkan dengan diskusi dan penyusunan materi secara online oleh masing-masing tim yang telah terbentuk. Diskusi via daring dengan menggunakan aplikasi WhatsApp ini bertujuan untuk tidak membentuk perkumpulan di tengah pandemi COVID-19. Hari berikut kegiatan, diadakan sosialisasi via daring dengan menggunakan aplikasi WhatsApp kepada masyarakat dan sosialisasi langsung atau tatap muka dengan salah satu warga di beberapa kelurahan. Indikator tercapainya kegiatan ini adalah timbulnya kesadaran masyarakat akan pentingnya menggunakan masker dan masyarakat mengetahui bagaimana cara membuang masker sekali pakai dengan benar dan cara membersihkan masker yang dapat digunakan secara berulang.

Sebelum sosialisasi diadakan, keluarga yang menerima sosialisasi tersebut belum mengetahui bahwa masker sekali pakai tidak dapat digunakan secara berulang dan cara tepat membersihkan masker yang dapat digunakan secara berulang. Namun, setelah diadakan sosialisasi baik secara langsung maupun via daring, keluarga tersebut sudah dapat membedakan antara masker sekali pakai dan masker yang dapat dipakai secara berulang. Keluarga tersebut juga sudah dapat mengetahui perbedaan masker medis dan masker non medis.

Materi sosialisasi yang disajikan dalam bentuk power point (PPT) dan bentuk leaflet. Yang akan disosialisasikan dan dibagikan kepada masyarakat setempat. Materi mencangkup Pentingnya menggunakkan masker, Perbedaan masker medis dan non medis, Cara menggunakkan dan membuang masker serta cara mencuci masker. Sosialisasi dilakukan di enam kecamatan berbeda sesuai dengan lokasi tempat tinggal peserta KKN yaitu kecamtan poasia, kecamatan kambu, kecamatan kendari barat, kec. Wua-wua, Kec. Puuwatu, dan Kec. Kendari.

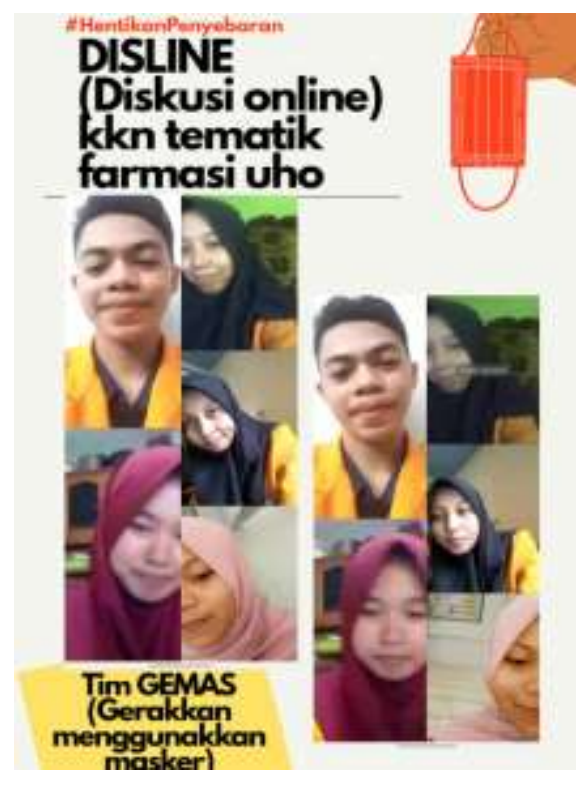

Gambar 1. Tim Melakukan Diskusi Online Penyusunan Materi Sosialisasi

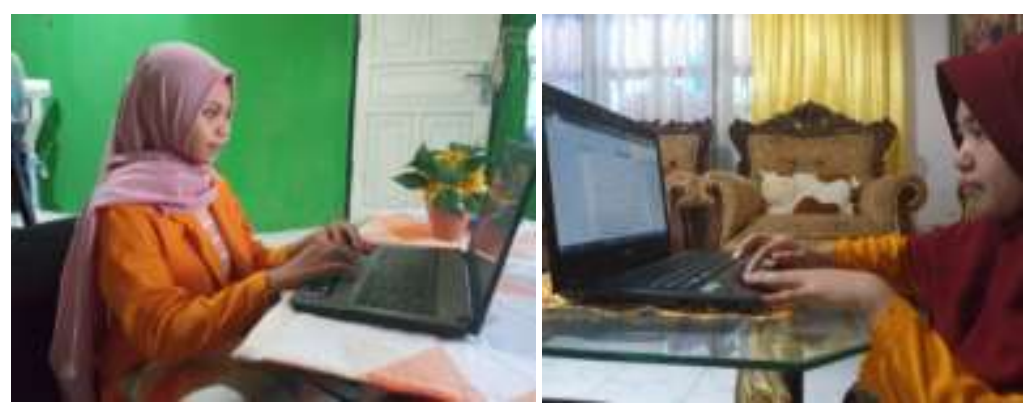

Gambar 2. Penyusunan materi sosialisasi dan pembuatan leaflet 
Hari pertama kegiatan dilaksanakan diskusi online mengenai materi yang akan disosialisasikan. Diskusi online dilaksanakan via whatsapp grup dan panggilan video guna didapatkan materi sosialisasi yang baik dan rinci. Materi sosialisasi dibuat dalam bentuk slide power point, leaflet, dan poster.

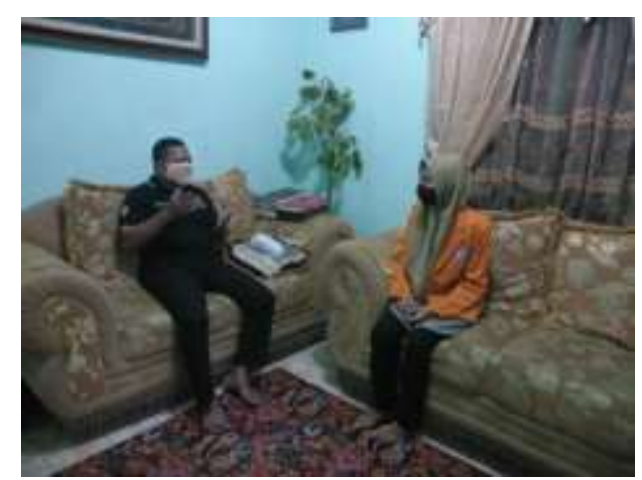

Gambar 3. Permintaan izin sosialisasi kepada RT setempat

Hari ketiga kegiatan, semua tim meminta izin kepada RT setempat untuk melaksanakan sosialisasi kepada warga baik melalui online maupun sosialisasi secara langsung. Kegiatan perizinan dilakukan dengan tetap mematuhi protocol kesehatan seperti menggunakan masker, jaga jarak dan tidak bersalaman. Hal ini dilakukan agar dapat menghindari penyebaran COVID19.

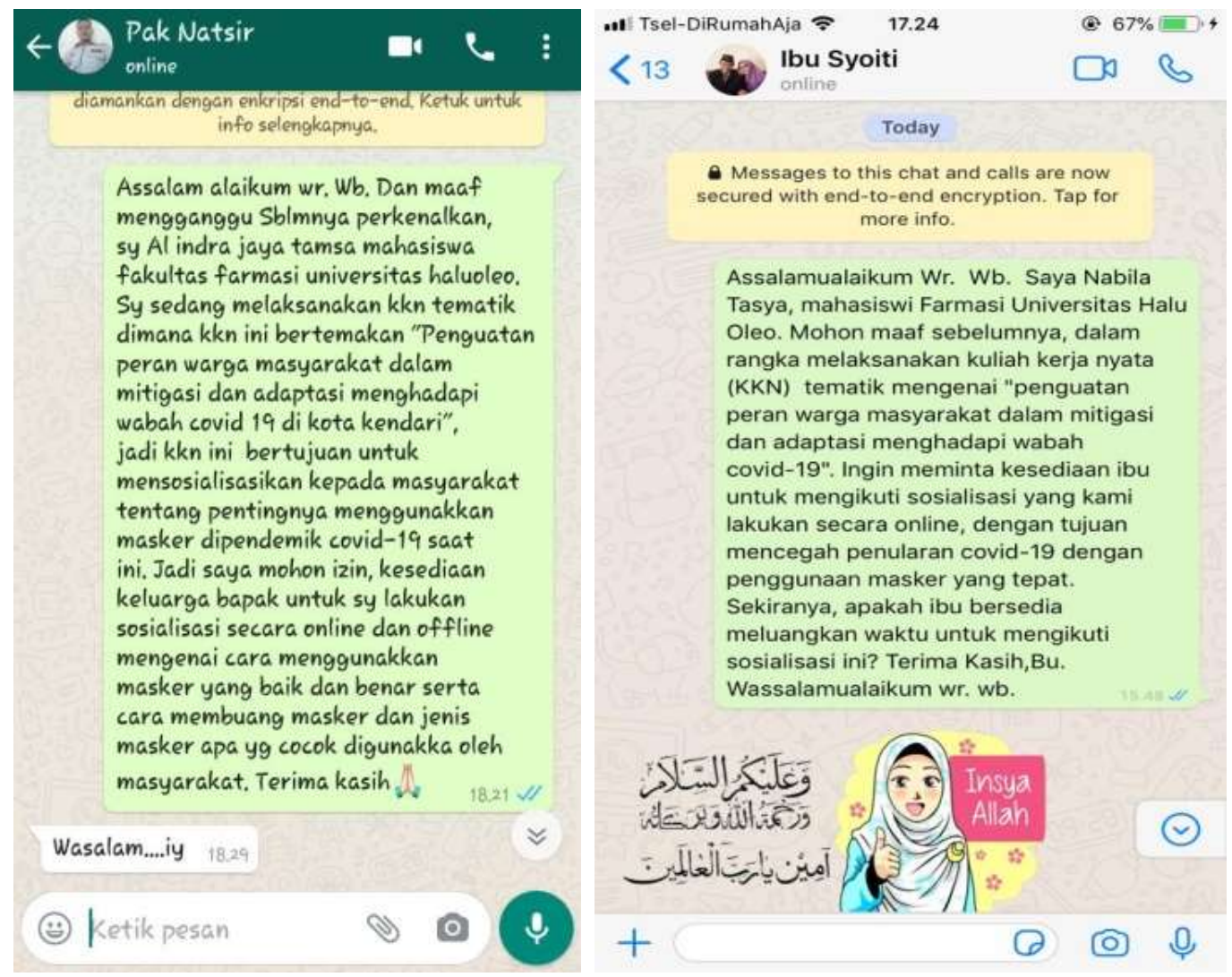

Gambar 4. Sosialisasi Gerakan Menggunakan Masker Via Whatsapp 


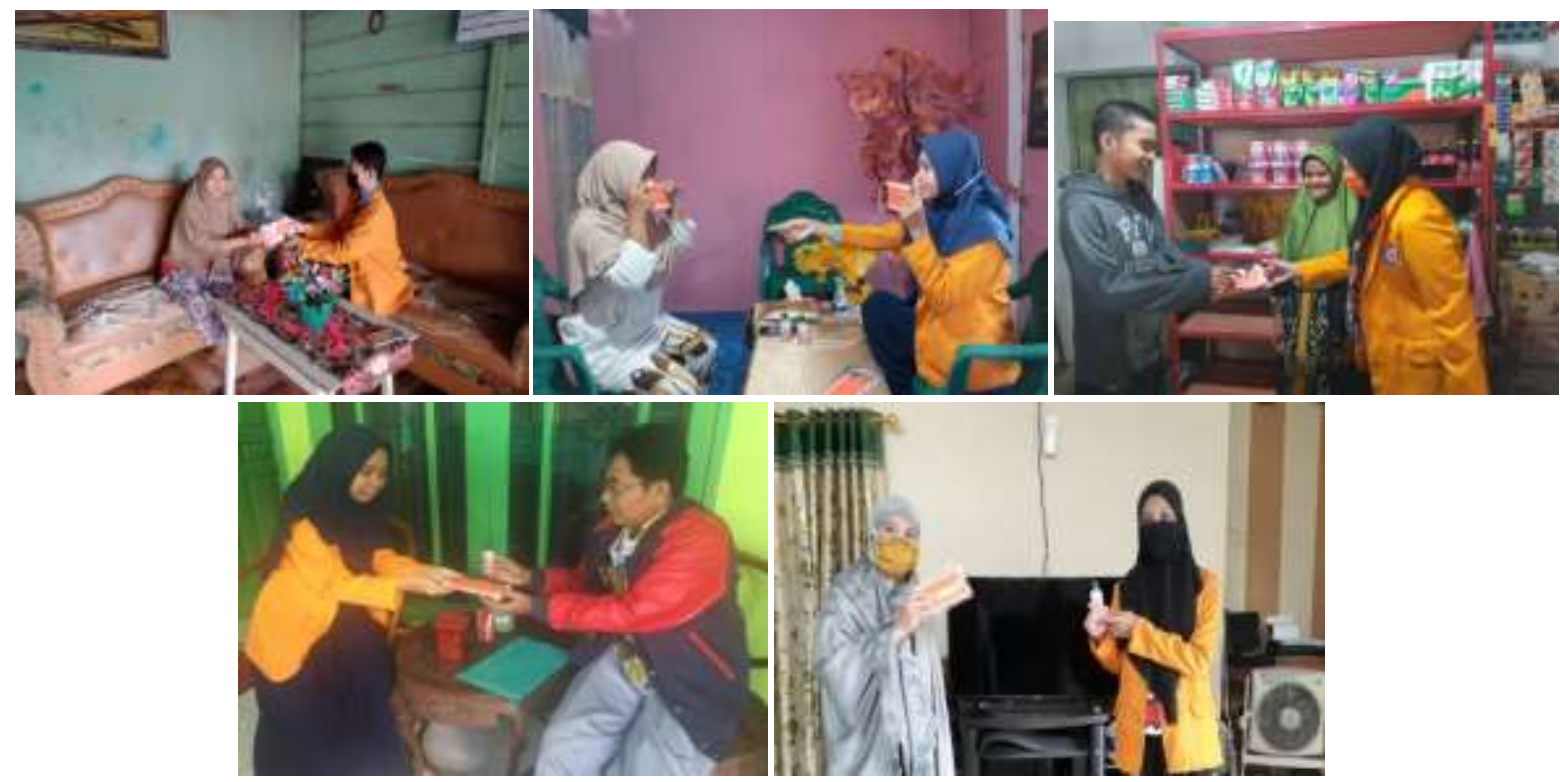

Gambar 5. Sosialisasi Langsung cara penggunaan Masker dan Pembagian Masker dan Handsanitizer kepada Warga

Hari ketiga dan keempat kegiatan dilaksanakan sosialisasi kepada warga di enam kecamatan tersebut baik secara online via whatsapp maupun secara langsung. Sosialisasi via watsapp membahas mengenai cara menggunakan masker, jenis-jenis masker, dan cara membuang masker sekali pakai dengan benar. Sosialisasi secara langsung dilaksanakan dengan tetap mematuhi protokol kesehatan degan tetap menggunakan masker dan menjaga jarak atau social distancing. Sosialisasi secara langsung membahas mengenai cara menggunakan masker non medis dan sekaligus membagikan masker dan handsanitizer kepada warga setempat.

\section{KESIMPULAN}

Kegiatan KKN Tematik 2020 dilaksanakan di Kota Kendari dengan tema Penguatan Peran Warga Masyarakat dalam Migrasi dan Adaptasi dalam Menghadapi Wabah Covid-19 di Kota Kendari. Melalui kegiatan KKN Tematik ini dilakukan agar masyarakat dapat mengetahui manfaat penggunaan masker dalam pencegahan Covid-19. Hasil dari Sosialisasi yang telah dilakukan yaitu masyarakat mematuhi anjuran menggunakan masker untuk mencegah penularan Covid-19. Kekurangan dari sistem sosialisasi yang dilakukan secara online yaitu beberapa masyarakat masih kurang paham terhadap penjelasan yang telah diberikan, maka dari itu perlunya sosialisasi secara offline agar dapat mempraktikan dan menjelaskan secara baik dengan bahasa yang mudah dipahami.

\section{UCAPAN TERIMA KASIH}

Penulis mengucapkan terima kasih kepada Lembaga Penelitian dan Pengabdian Masyarakat Universitas Halu Oleo yang telah mendanai kegiatan Pengabdian Kepada Masyarakat terintegrasi KKN Tematik Covid-19 Tahun 2020

\section{DAFTAR PUSTAKA}

Armiani, S., Siti R. F., Akhmad S., dan Baiq Y. P.(2020). Pelatihan Pembuatan Masker Sebagai Upaya Antisipasi Penyebaran Covid-19 di Desa Anyar Kabupaten Lombok Utara, Jurnal Pengabdian UNDIKMA, 1(1).

Athena., Eva L., dan Tities P., 2020, Pelaksanaan Disinfeksi Dalam Pencegahan Penularan Covid-19 
Dan Potensi Risiko Terhadap Kesehatan Di Indonesia, Jurnal Ekologi Kesehatan, Vol. 19(1).

Dewi, N. A. P., dan Sri U. (2020). Perancangan Masker Kain Sebagai Alat Pelindung Diri dalam Sistem Suntainable Fashion.Jurnal Da Moda, 1(2).

Indrawati., Dwi. K. R., dan Leny F., 2020, Masker Gratis dan Informasi Social Distancing Bagi Masyarakat Dusun Motong Are Tengah, Intan Cendekia (Jurnal Pengabdian Masyarakat), Vol. $1(1)$.

Natalia, R. N., Evelin M., dan Yunus E., 2020, Kesiapsiagaan Remaja dalam Menghadapi Wabah Covid-19, Jurnal Ilmiah Kesehatan Diagnosis, Vol. 15(2).

Sari, D. P., Nabila S., dan Atiqoh, 2020, Hubungan Antara Pengetahuan Masyarakat dengan Kepatuhan Penggunaan Masker Sebagai Upaya Pencegahan Penyakit Covid-19 di Ngronggah, INFOKES, Vol. 10(1).

Telaumbanua, D., 2020,Urgensi Pembentukan Aturan Terkait Pencegahan Covid-19 di Indonesia, Jurnal Pendidikan, Sosial, dan Agama, Vol.12(1).

Yuliana. (2020). Corona Virus Deseases (Covid-19) : Sebuah Tinjauan Literatur, Wellness and Healthy Magazine, 1(2).

Yunus.N.R., dan Annissa.R., 2020, Kebijakan Pemberlakuan Lockdown Sebagai Antisipasi Penyebaran Corona Virus Covis-19., Jurnal Sosial \& Budaya Syar-i, Vol.7(3).

Zendrato., W., 2020, Gerakan Mencegah Daripada Mengobati TerhadapPandemi Covid-19, Jurnal Education and development, Vol. 8(2). 